胃癌切除症例に扣ける漿膜面浸潤の検討

\begin{tabular}{llclll}
\multicolumn{5}{c}{ 広島大学原医研外科 } & \\
佐伯 & 俊昭 & 田中 & 卓 & 西山 & 正彦 \\
万代 & 光一 & 吉中 & 建 & 柳川 & 悦朗 \\
峠 & 哲哉 & 新本 & 稔 & 服部 & 孝雄
\end{tabular}

\title{
CLINICAL STUDY ON RESECTABLE GASTRIC CANCER WITH SEROSAL INVASION
}

\section{Toshiaki SAEKI, Takashi TANAKA, Masahiko NISHIYAMA, Koh-ichi MANDAI, Ken YOSHINAKA, Eturo YANAGAWA, Tetuya TOGE, Minoru NIIMOTO and Takao HATTORI}

Department of Surgery, Research Institute for Nuclear Medicine and Biology, Hiroshima University

胃癌切除例の肉眼的漿膜面浸潤程度之臨床病理学的所見ならびに予後との関係をみるため, 当科で 切除された1,097症例について検討を加えた。組織型との関保は， $\mathrm{S}_{0}, \mathrm{~S}_{1}$ では高分化型が多く $\mathrm{S}_{2}, \mathrm{~S}_{3}$ で は低分化型が多かった，5年生存率は， $\mathrm{S}_{0} 72.3 \% ， \mathrm{~S}_{1} 63.1 \%, \mathrm{~S}_{2} 29.8 \%, \mathrm{~S}_{3} 8.2 \%$ であった。腹膜 再発との関係は，初回手術時腹膜転移陰性で腹膜再発によるイレウスを発症した 37 症例について検討 すると $\mathrm{S}_{2}$ が31例と最も多く，組織型では por が28例と多かった. $\mathrm{S}_{3}$ 症例では合併切除の意義が認めら れた，以上より低分化型で $\mathrm{S}_{2}$ 以上の症例では，腹膜再発が抗こることを念頭に招き経過観察する必要 があり, 再発時の治療には，手術を中心とした集学的治療が有用であると思われた。

索引用語：胃癌切除症例, 胃癌漿膜面浸潤程度, 進行胃癌他臓器合併切除, 腹膜播種性イレウス

\section{I.はじめに}

胃癌切除症例の漿膜面浸潤 $(\mathrm{S})^{1 /}$ は, 肝転移, 腹膜転 移、リンパ節転移とともに胃癌の予後を決定する重要 な因子であるが, 癌巣の直接漫潤といった観点からは, 他の 3 因子に比べ生物学的に異なっていると考学られ る、しかし，腹膜転移とは従来から密接な関係がある といわれ，それ故潜在的に予後を決定する可能性があ る.そこで当教室で経験した胃癌切除症例を臨木病理 学的に検討し, 胃癌症例の予後に括ける S 因子の意 義, ならびに肉眼的他臟器漫潤胃癌 $\left(\mathrm{S}_{3}\right.$ 症例) の外科 的治療も含めた集学的治療について文献的考察を加之 報告する。

\section{II. 症例ならびに研究方法}

昭和 48 年 6 月から昭和 61 年 12 月までの間の胃癌切除

<1988年 8 月26日受理>別刷請求先：佐伯 俊昭 =734 広島市南区霞 $1-2-3$ 広島大学原医研外 科
症例は1,097例であり，それらを胃癌取扱い規約1)よ る墏膜面浸潤の程度で分けると， $\mathrm{S}_{0} 417$ 例 $(38.0 \%)$ $\mathrm{S}_{1} 116$ 例 (10.6\%) $\mathrm{S}_{2} 390$ 例 (35.6\%) $\mathrm{S}_{3} 174$ 例 (15.9\%) であった。これらを対象とし，S因子と腹膜転移(P)， 肝転移 $(\mathrm{H})$, リンパ節転移 $(\mathrm{N})$ などの因子との関俰, 組織型，合併切除の意義，腹膜再発括上び遠隔成績に ついて検討した，有意差検定には $\chi^{2}$ 検定，生存率の検 定は Kaplan-Meier 法を用いた。

\section{III. 成 績}

1. $\mathrm{S}$ 因子と $\mathrm{P}, \mathrm{H}, \mathrm{N}$ 因子との関係 腹膜転移陽性例は $\mathrm{S}_{0} 0$ 例 ( $\left.0 \%\right) \mathrm{S}_{1} 4$ 例 (3.4\%) $\mathrm{S}_{2}$ 111 例 $(32.8 \%) \mathrm{S}_{3} 110$ 例 (62.5\%) であった。 また， 肝転移陽性例は $\mathrm{S}_{0} 2$ 例 $(0.5 \%), \mathrm{S}_{1} 5$ 例 $(4.2 \%), \mathrm{S}_{2}$ 34 例 (10.1\%), $\mathrm{S}_{3} 28$ 例 (15.9\%) で，リンパ節転移 陽性例は $\mathrm{S}_{0} 80$ 例 (7.3\%) $\mathrm{S}_{1} 83$ 例 (71.6\%) $\mathrm{S}_{2} 338$ 例 (86.7\%) $\mathrm{S}_{3}$ 170例 (96.6\%) に認められた（表 1$)$.

2.S因子と病理組織学的所見 
表 1 胃癌切除症例に劣けるS 因子と他因子との関係

\begin{tabular}{|c|c|c|c|c|c|c|c|}
\hline \multirow{2}{*}{\multicolumn{2}{|c|}{ S 在 例 数 }} & \multicolumn{2}{|c|}{$\mathrm{P}$} & \multicolumn{2}{|c|}{$\mathrm{H}$} & \multicolumn{2}{|c|}{$\mathrm{N}$} \\
\hline & & + & - & + & - & + & - \\
\hline 0 & $417(38.0)$ & $0(0)$ & 417 (100) & $2(5)$ & 415 (95) & 80 (19) & 337 (81) \\
\hline 1 & $116(10.6)$ & $4(3)$ & $112(97)$ & $5(4)$ & 111 (96) & $83(72)$ & 33 (28) \\
\hline 2 & $390(35.6)$ & $111(28)$ & $279(72)$ & $34(9)$ & 356 (91) & 338 (87) & $52(13)$ \\
\hline 3 & $174(15.8)$ & $110(63)$ & $64(37)$ & $28(16)$ & $146(84)$ & $170(98)$ & $4(2)$ \\
\hline 合計 & $1097(100)$ & $225(21)$ & $872(79)$ & $69(6)$ & 1028 (94) & $671(61)$ & 426 (39) \\
\hline
\end{tabular}

表 2 胃癌切除症例における肉眼的漿膜面浸潤と組織学的深達度

\begin{tabular}{|c|c|c|c|c|c|c|}
\hline \multicolumn{2}{|c|}{ 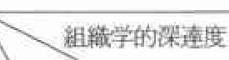 } & \multicolumn{5}{|c|}{ ps } \\
\hline & & \multirow{2}{*}{$\frac{-}{\mathrm{m} \sim \mathrm{ss} \beta}$} & \multicolumn{4}{|c|}{+} \\
\hline $\mathrm{S}$ & 昰例 & & ss $\gamma$ & se & sei (si) & 一政帮 $(\%)$ \\
\hline 0 & 417 & $396^{*}$ & 21 & 0 & 0 & 95.0 \\
\hline 1 & 116 & 68 & $27^{*}$ & $21^{*}$ & 0 & 41.1 \\
\hline 2 & 390 & 100 & $61^{*}$ & $221^{*}$ & 8 & 72.3 \\
\hline 3 & 174 & 15 & & 93 & $66^{*}$ & 37.9 \\
\hline 計 & 1097 & 579 & 109 & 335 & 74 & \\
\hline
\end{tabular}

*漿膜画浸潤程度に相応する深達度

表 3 胃癌切除症例に拈けるS 因子と組織型

\begin{tabular}{|c|c|c|c|c|c|c|c|c|c|c|}
\hline 分化度 & & & 化 & & \multicolumn{5}{|c|}{ 低 分 化 } & \multirow{2}{*}{ 総計 } \\
\hline S】 組織型 & pap & tubl & tub2 & 計 & por & sig & muc & その他 & 計 & \\
\hline 0 & 29 & 97 & $\begin{array}{c}120 \\
(59.0)\end{array}$ & 246 & 110 & 42 & 10 & 9 & $\begin{array}{c}171 \\
(41.0)\end{array}$ & 417 \\
\hline 1 & 13 & 8 & $\begin{array}{c}35 \\
(48.3)\end{array}$ & 56 & 51 & 4 & 4 & 1 & $\begin{array}{c}60 \\
(51.7)\end{array}$ & 116 \\
\hline 2 & 8 & 34 & $\begin{array}{c}107 \\
(38.2)\end{array}$ & 149 & 192 & 28 & 14 & 7 & $\begin{array}{c}241 \\
(61.8)\end{array}$ & 390 \\
\hline 3 & 15 & 7 & $\begin{array}{c}41 \\
(36.2)\end{array}$ & 63 & 88 & 2 & 16 & 5 & $\begin{array}{c}111 \\
(64.8)\end{array}$ & 174 \\
\hline 計 & 65 & 146 & 303 & $\begin{array}{c}514 \\
(46.9)\end{array}$ & 441 & 76 & 44 & 22 & $\begin{array}{c}583 \\
(53.1)\end{array}$ & $\begin{array}{c}1097 \\
(100)\end{array}$ \\
\hline
\end{tabular}

組織学的深達度では $\mathrm{S}$ 因子と予後的漿膜面因子 (ps) とを検討すると, $\mathrm{S}_{0}$ は ps (一) 396例, ps (十) 21例, $\mathrm{S}_{1}$ は, ps (-) 68例, ps $(+) 48$ 例, $\mathrm{S}_{2}$ は ps $(-)$ 100例, ps (+) 290例, $\mathrm{S}_{3}$ は ps (-) 15例, ps (+) 159例であった. 肉眼的漿膜面浸潤と組織学的深達度の 一致率を検討すると， $\mathrm{S}_{0}$ で ps（一）の症例は396例で $95.0 \%$ でった. $\mathrm{S}_{1} \cdot \mathrm{S}_{2}$ は組織学的には深達度 $\mathrm{ssr}+\mathrm{se}$ に相当するが, $\mathrm{S}_{1}$ は116例中48例(41.1\%)， $\mathrm{S}_{2}$ は390例 中 282 例 $(72.3 \%)$ の一致率であった. $\mathrm{S}_{3}$ は sei が66例 で37.9\%であった（表 2 ).
組織型は， $\mathrm{S}_{0}$ は $\mathrm{tub}_{2}(28.7 \%)$, por $(26.4 \%)$, tub (23.3\%), pap (6.9\%), sig (10.1\%), muc (2.4\%) の順で, pap, tub tub $_{2}$ を高分化型とし, por, sig, mucを低分化型に分けて検討すると，それぞれ $58.9 \%, 38.9 \%$ であった. $\mathrm{S}_{1} \cdot \mathrm{S}_{2}$ では por の占める割 合が多くなり, $\mathrm{S}_{3}$ では por $(50.6 \%), \operatorname{tub}_{2}(23.6 \%)$, $\operatorname{pap}(8.6 \%), \operatorname{tub}_{1}(4.0 \%), \operatorname{muc}(9.2 \%), \operatorname{sig}(1.1 \%)$ の順で，高分化型は $36.2 \%$ ，低分化型は60.9\%であっ た(表 3 )。

漿膜面浸潤と腫場径の関係を検討すると S 因子別 
の最大径の平均值は $\mathrm{S}_{0} 3.2 \mathrm{~cm}, \mathrm{~S}_{1} 4.9 \mathrm{~cm}, \mathrm{~S}_{2} 7.7 \mathrm{~cm}$, $\mathrm{S}_{3} 9.7 \mathrm{~cm}$ であり, 当然の事ながら, 腫瘍径が大きくな るにつれて漿膜面浸潤程度が著しくなっていた。

根治度との関係をみると, 組織学的には $\mathrm{S}_{0}$ は, 絶対 治瘑切除 (absolute curative, a-c と略す) 380例 (91.1\%)，相対治癒切除 (relative curative, r-c 々略 す) 26 例 $(6.2 \%$ ), 相対非治癒切除 (relative noncurative, r-n と略す) 1 例 (0.2\%), 絶対非治瘾切除 (absolute noncurative, a-n と略す) 10例 (2.4\%) で あった． $\mathrm{S}_{1}$ は a-c 71例 (61.2\%), r-c 29例 (25.0\%)， r-n 9 例 $(7.8 \%)$, a-n 7 例 $(6.0 \%)$ であり, $\mathrm{S}_{2}$ はa-c 127 例 $(32.6 \%), r-c 97$ 例 $(24.9 \%), r-n 33$ 例 (18.5\%), a-n 133例（34.1\%）であった. $\mathrm{S}_{3}$ は a-c 6 例 (3.6\%), r-c 18例(10.8\%), r-n 12例(7.2\%), a-n 131例(78.4\%) であり， $\mathrm{S}_{0}$ では絶対治癒切除が，また $\mathrm{S}_{3}$ では絶対非治 癒切除症例が多くなっていた。

3. $\mathrm{S}_{3}$ 症例に打ける合併切除

$\mathrm{S}_{3}$ 症例の浸潤藏器について検討すると, 膵臓 137 例,

表 4 イレウス発症が腹膜再発による症例の S 因子と 組織型

\begin{tabular}{cc}
\hline S因子 & 症例数 \\
\hline 0 & $0(\quad 0)$ \\
1 & $1(2.7)$ \\
2 & $31(83.8)$ \\
3 & $5(13.5)$ \\
\hline & $37(100)$ \\
\hline 組織型 & 症例数 \\
\hline por & $28(74.7)$ \\
muc & $1(2.7)$ \\
sig & $2(5.4)$ \\
tub2 & $6(16.2)$ \\
\hline & $37(100)$
\end{tabular}

結腸18例, 肝臓14例で, 合併切除を行った臓器として は膵臓18例，結腸18例，肝臓 8 例（ただし，膵臓十結 腸 1 例, 脾臓十膵藏土結腸 1 例, 脾葴 + 膵臓 2 例を含 む)であった。各臓器別切除率を求めると, 膵缄 $27.8 \%$, 結腸 $100 \%$ ，肝臓 $57.1 \%$ となった。捭臓はリンパ節 郭清のために合併切除されたもので，腫瘍の直接浸潤 が認められたるのはなかったので除外した。合併切除 症例亡非合併切除症例の予後について検討すると, 有 意差は認められなかったものの3 年生存率は合併切除 群 $8 \%$, 非切除群 $3.5 \%$ となり, 合併切除群に生存率の 高い傾向が認められた(図2).

4.S因子と腹膜再発

開腹時腹膜播種性転移 (P) 因子陰性例で, その後腹 膜再発を認め, さらに予後を決定するようなイレウス 症状を発現した症例は37例であり，S因子別にみると $\mathrm{S}_{0}$ は 0 例, $\mathrm{S}_{1}$ は 1 例 (2.5\%), $\mathrm{S}_{2}$ は31例 (77.5\%), $\mathrm{S}_{3}$

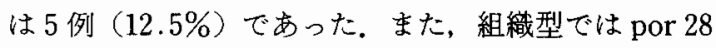
例, $\operatorname{tub}_{2} 6$ 例, sig 2 例, muc 1 例であった（表 4 ). イレウス発症迄の期間は， $S_{1}$ の 1 例においては 1 年以 内に再発しており，これは組織学的にはss $\gamma$ であっ た. $\mathrm{S}_{2}$ の31例では, 最初の 1 年以内に 12 例の再発を認 め, 3 年以内に 26 例 $(83.8 \%)$ が再発していた. $\mathrm{S}_{3}$ は, 1 年以内が 3 例， $3 \sim 4$ 年目に 2 例の再発が認められ た（表 5 ). 治㞠は, OK-432（ピシバニール）を $100 \mathrm{~K}$. E. 腹腔内に投与した症例の生存率が，無投与症例に比 ベ有意差は認められないもののよい傾向にあった（図 3）.な挌各症例のイレウス発症までの期間は平均 2.4 年であった。

5. 遠隔成績

早期胃癌を除く $\mathrm{S}$ 因子別の 5 年生存率は, $\mathrm{S}_{0}$ 症例で は72.3\%, $\mathrm{S}_{1}$ は63.1\%, $\mathrm{S}_{2}$ は29.8\%, $\mathrm{S}_{3}$ は8.2\%であっ た（図 1 ).

表 5 再発症例のイレウス発症までの期間

\begin{tabular}{|c|c|c|c|c|}
\hline 年 & $\mathbf{S}_{1}$ & $\mathrm{~S}_{2}$ & $\mathrm{~S}_{3}$ & 合 \\
\hline $0-1$ & 1 & 12 & 3 & $16(43.3)$ \\
\hline $1-2$ & 0 & 8 & 0 & $8(21.6)$ \\
\hline $2-3$ & 0 & 6 & 0 & $6(16.2)$ \\
\hline $3-4$ & 0 & 1 & 2 & $3(8.1)$ \\
\hline $4-5$ & 0 & 1 & 0 & $1(2.7)$ \\
\hline $5-6$ & 0 & 3 & 0 & $3(8.1)$ \\
\hline 合 計 & $1(2.7)$ & $31(83.8)$ & $5(13.5)$ & $37(100)$ \\
\hline
\end{tabular}


図 1 S 因子別の 5 年生存率 (Kaplan-Meier 法)

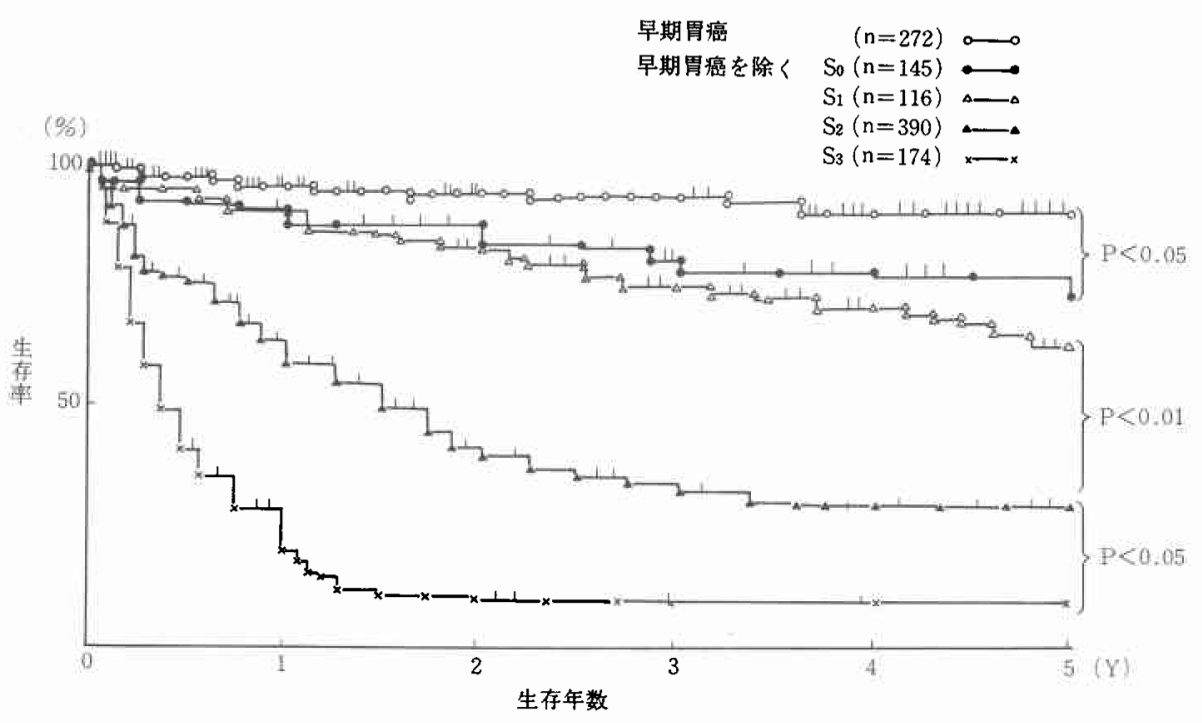

図 $2 \mathrm{~S}_{3}$ 症例における生存率

一合併切除と非合併切除との比較一

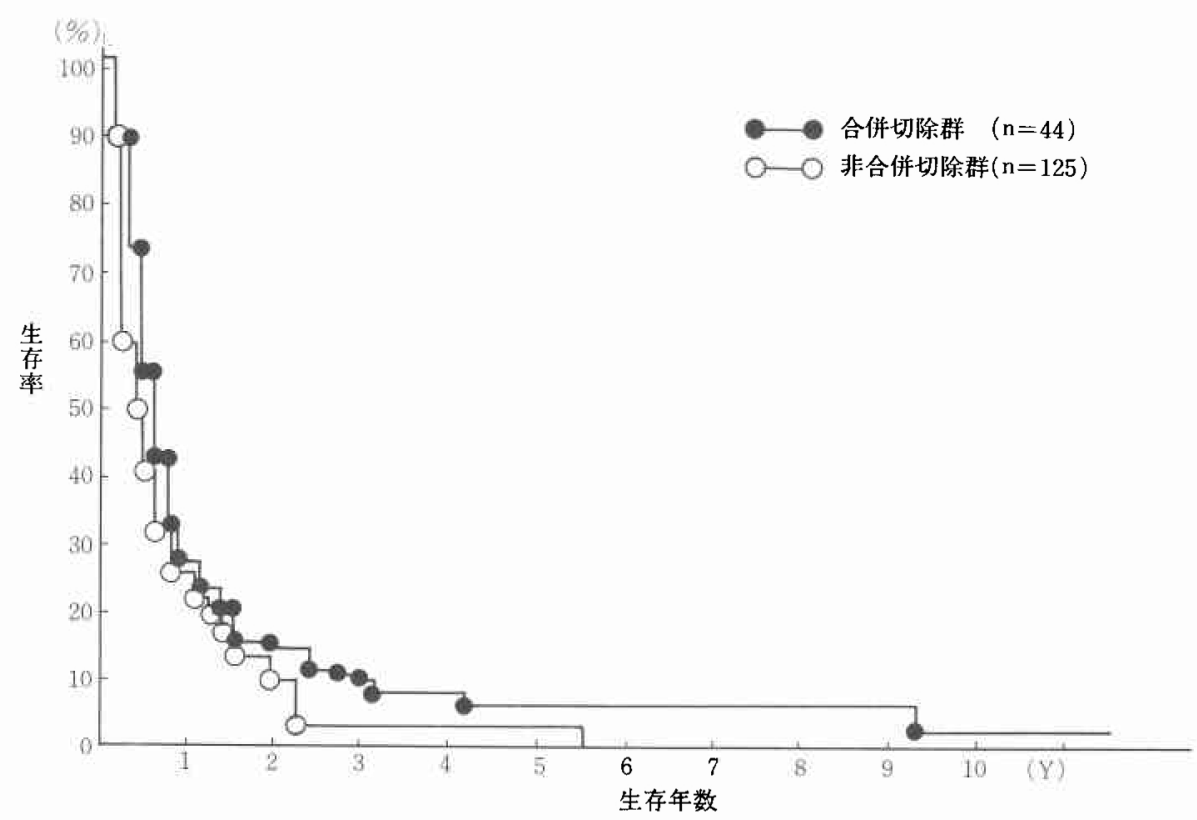

IV. 考案

全国胃がん登録調查報告2)によると 4,554 症例の S 因子の内訳は, $\mathrm{S}_{0} 1,700$ 例 (37.3\%) $\mathrm{S}_{1} 506$ 例 (11.1\%) $\mathrm{S}_{2}$ 1,708例 (37.5\%) $\mathrm{S}_{3}$ 625例 (13.7\%) であり，当 教室の 1,097 例の内訳とほぼ一致している.S 因子と他 の因子との関係について検討すると，P因子陽性率は
全国では $\mathrm{S}_{0} 0.4 \%, \mathrm{~S}_{1} 4.3 \%, \mathrm{~S}_{2} 19.4 \%, \mathrm{~S}_{3} 39.8 \%$ であるのに対し，当教室では， $\mathrm{S}_{0} 0 \%, \mathrm{~S}_{1} 3.4 \%, \mathrm{~S}_{2}$ $32.8 \%, \mathrm{~S}_{3} 39.8 \%$ であり全国集計に比べ $\mathrm{S}_{2}$ に $\mathrm{P}$ 因子 陽性例が多く,このことは $\mathrm{S}_{2}$ の症例の再発例の中に $\mathrm{P}$ 再発が多く,予後にも影響していることが示唆された。 肝転移陽性率では, 各將膜面浸潤に括ける全国と当教 
図 3 腹膜播種イレウスの累積生存率

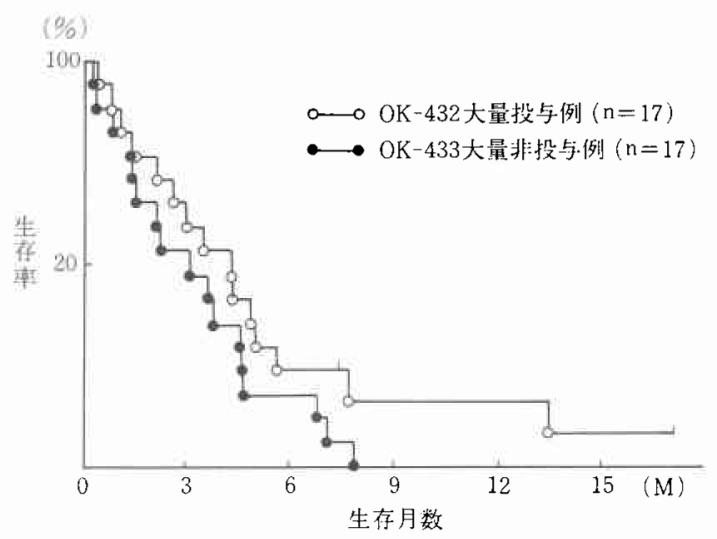

室の統計では，それぞれ $\mathrm{S}_{0} 0.5 \% \rightarrow 0.5 \%, \mathrm{~S}_{1} 2.8 \% \rightarrow$ $4.2 \%, \mathrm{~S}_{2} 4.6 \% \rightarrow 10.1 \%, \mathrm{~S}_{3} 13.1 \% \rightarrow 15.9 \%$ となり $\mathrm{S}_{1}, \mathrm{~S}_{2}$ に有意差は無いがわれわれの症例の方が肝転移 率が高かった、つぎに、リンパ節転移率では， $\mathrm{S}_{0} 3.7 \%$ $\rightarrow 7.3 \%, \mathrm{~S}_{1} 77.3 \% \rightarrow 71.6, \mathrm{~S}_{2} 98.7 \% \rightarrow 86.7 \%, \mathrm{~S}_{3}$ $97.6 \% \rightarrow 96.6 \%$ と若干の数値の差はあるが, $\mathrm{S}_{1}$ 以上で は70\%以上のリンパ節転移が認められた。

漿膜面浸潤と組織学的深達度との関係は, 出来るだ け同一の術者によるS因子の判断にもとついた集計 にも関わらず $\mathrm{S}_{3}$ では一致率が低くなったが, 病理組織 学的には摘出標本にかならずしも浸潤藏器が付着して いるとは限らず, とくに膵蔵, 肝蔵に直接浸潤する場 合で, 合併切除を行っても se としか判定出来ない症例

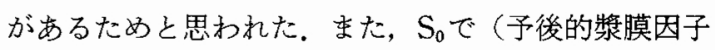
陽性) ps (十)）と判定した21症例のうち消化性潰瘍を 合併していたものが16例，粘膜下にび漫性に浸潤して いたものが 2 例, 胃周囲炎により漿莫面浸潤の判定が 困難であったものが 3 例であった。

組織型との関係をみると，押淵ら ${ }^{3)}$ は， $\mathrm{S}_{0}$ では pap， tubなどの分化型が多く， $\mathrm{S}_{3}$ では逆に porなどの低分 化型が多かったと報告しているが，当科においても分 化度が低くなるほど漿膜面浸潤が進さ傾向が認められ た。

腫瘍径と漿膜面浸潤については，いわば垂直方向の 浸潤度 (漿膜浸潤) と水平方向の浸潤度（腫瘍径）と は明らかに比例していた。しかし，中島ら4によれば， 粘膜面での広がりよりもしろ漿膜面での癌の広がりが 重要であり, その根拠は腹腔遊離癌細胞の出現が, 漿 膜面での癌の広がりと密接な関係があるためとしてい る.当科に沶ける弘野ら ${ }^{5)}$ の術中腹腔細胞診の検討で
は $\mathrm{S}_{2}$ 抢よび $\mathrm{S}_{3}$ 症例の128例中 5 例 $(4.0 \%$ ) にしか Class IV V V を認めず，細胞診の際の検体の採取方法 なども含め，異論のあるところである。

根治度については， $\mathrm{S}_{2}$ までは治癒切除が $50 \%$ 以上で

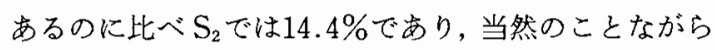
$\mathrm{S}_{3}$ 症例での治癒切除は困難で, $\mathrm{S}_{3}$ での $\mathrm{H}(-), \mathrm{P}(-)$ 症例では, 浸潤葴器, そして合併切除の有無が予後に 大きく影響していると思われた。

浸潤藏器で最も多いのは膵臓であるが, 合併切除率 では低く，これらS 因子以外の因子により既に根治性 がなく，危険を犯してまで脺頭十二指腸切除を行らほ ぞの意味がない症例が大部分を占めていたと思われ た. 白壁ら $6 \mathrm{~S}_{3}$ 症例の浸潤葴器に括ける合併切除に 関する検討では，膵体尾部および結腸間膜に浸潤した 症例の切除の意味を強調しているが，われわれの症例 でも遠隔成績で検討すると，合併切除群之非合併切除 群では有意差は認められなかったものの，切除群に生 存期間の延長が認められた。

$\mathrm{S}$ 因子と腹膜再発の関係については,イレウス症状 にて当科再入院し治療を行った 37 例の検討では, $\mathrm{S}_{2}$, $\mathrm{S}_{3}$ 症例で高率に再発が認められた。これは全 $\mathrm{S}_{2}, \mathrm{~S}_{3}$ 症

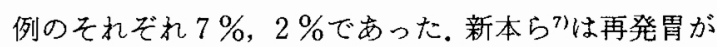
んの腹膜転移によるイレウスにビシバニールの $100 \mathrm{~K}$. E. を腹腔内に散布する治療法が効果的であると報告 しているが，今回の検討でも大量投与に生存期間の延 長が認められた。漿膜面浸潤程度による遠隔成績につ いては，当然のことながらS 因子が進むにつれて予後 は悪くなるが, $\mathrm{S}_{0}+\mathrm{S}_{1}, \mathrm{~S}_{2}+\mathrm{S}_{3}$ の 2 群にわけて生存率 の検討を行らとそれぞれ77.7\%，23.1\%となり，有意 の差を認めた。

この成績から現在当科では胃癌術後補助免疫化学療 法に $\mathrm{S}_{0}+\mathrm{S}_{1}, \mathrm{~S}_{2}+\mathrm{S}_{3}$ の 2 群に層別化したらえで recombinant human interferon- $\alpha$ (HLBI) を用いた prospective randomized controlled trial を行ってお り，この成績が待たれるところである。

\section{おわりに}

当科で切除された胃癌症例の漿膜面浸潤について病 理組織学的検討を加光，次のような結果をえた。

1. 漿膜面浸潤が進さにつれて, 腹膜転移陽性率が高 くなった.

2. 5 年生存率では早期胃癌を除いた $\mathrm{S}_{0} 72.3 \%, \mathrm{~S}_{1}$ $63.1 \%, \mathrm{~S}_{2} 29.8 \%, \mathrm{~S}_{3} 8.2 \%$ あった(Kaplan-Meier 法). $\mathrm{S}_{0}+\mathrm{S}_{1}, \mathrm{~S}_{2}+\mathrm{S}_{3}$ の 2 群での生存率を比較すると, それぞれ77.7\%，23.1\%となり有意差を認めた（p< 
0.05).

3. 初回手術時 $\mathrm{P}$ 因子陰性例の腹膜再発症例は37症 例 (4.2\%)で，漿膜面浸潤では $\mathrm{S}_{2}$ が多く，イレウス発 症までの平均期間は 2.4 年, 組織型では低分化型が多 かった.

\section{文献}

1）胃癌研究会編：胃癌取扱い規約. (改訂版第10版). 金原出版，東京，1979

2）胃癌研究会, 国立ガンセンター, 三輪胃がん登録研 究所編：全国胃がん登録調查報告(第22号)。東京, 1976

3）押淵英晃, 大津哲雄, 池田良一澡か：胃澏における 漿膜面漫潤程度の臨床的評価。臨外 $43: 404$
$-411,1982$

4）中島聰總，小鍜治明照，高木国夫注か：胃癌取扱い 规約における墏膜漫鬥度および Stage 分類の問題 点. 手術 $36: 539-544,1982$

5）弘野正司, 中上和彦,松木 啓ほか；胃がんに括け る開腹時腹腔細胞診。消外 $6: 217-222,1983$

6）白壁勝哉, 高木国夫, 高橋利云汪か：肉眼的他臓器 浸閏胃癌切除例の検討. 日消外会誌 $19: 2196$ $-2202,1986$

7）新本 稔，中上和彦, 弘野正司注か：胃がん非治㦄 切除症例化対する再手術による化学療法の效果の 検討。癌の臨 $29 ： 1274-1278,1983$ 